doi

https://doi.org/10.31869/ruhama.v4i2799

\title{
The Role of Parents and Teachers in Fostering Interest in Memorizing the Koran for Students in The New Normal
}

\author{
Ernita \\ Universitas Muhammadiyah Sumatera Barat, Indonesia \\ e-mail: ernitasabidun1@gmail.com
}

ARTICLE INFO

Article History:

Received: June 24, 2021

Revised: August 20, 2021

Accepted: October 04, 2021

Published: October 31, 2021

*Corresponding

Author:

Name: Ernita

Email:

ernitasabidun1@gmail.c om

Phone/WA:

085263736113

\section{ABSTRACT}

Learning for students in the new normal period requires the main role of parents and teachers. The role of both determines interest in memorizing the Qur'an for students in the new normal period. The purpose of this study is to determine the role of parents and teachers during tahfiz learning for students, the role of parents and teachers in an effort to foster interest in learning tahfiz students, forms of collaboration between parents and teachers in order to foster interest in learning tahfiz and the level of memorization of participants. Studied at MTsN 2 Pasaman. This research method is based on a descriptive qualitative approach. The results of the research in this thesis are determined by the level of knowledge, the presence of parents, and interactions. So, students who have parents with good insight into tahfiz knowledge, and are more at home, then the role of parents can be given in full in tahfiz learning. On the other hand, students who have parents with less knowledge or knowledge of tahfiz, and are busy working, have a limited role in their children's tahfiz learning activities. Parents provide encouragement, messages, advice, sanctions and rewards to their children. This is done in order to foster interest in learning tahfiz students who study at madrasas or at home. Therefore, parents have performed their roles as motivators, educators, discipline enforcers, and regulators or controllers. The role of parents depends on the level of knowledge and basic tahfiz, as well as the intensity of the meeting between parents and students in interacting while at home.

\section{Abstrak}

Pembelajaran peserta didik di masa new normal membutuhkan peran utama dari orang tua dan guru. Peran keduanya menentukan minat dalam menghafal Alquran bagi peserta didik di masa new normal. Tujuan pada penelitian ini yaitu guna mengetahui peran orang tua dan guru selama melakukan pembelajaran tahfiz peserta didk, peran orang tua beserta guru dalam upaya menumbuhkan minat belajar tahfiz peserta didik, bentuk kerja sama orang tua beserta guru dalam rangka menumbuhkan minat belajar tahfiz dan tingkatdaya hafal peserta didik di MTsN 2 Pasaman. Metode penelitian ini berdasarkan pada pendekatan kualitatif secara deskriptif. Hasil penelitian pada tesis ini ditentukan oleh tingkat pengetahuan, keberadaan orang tua, dan interaksi. Jadi, siswa yang memiliki orang tua dengan wawasan pengetahuan tahfiz juga baik, dan berada lebih banyak di rumah, maka peran orang tua dapat 
diberikan secara utuh dalam pembelajaran tahfiz. Sebaliknya, siswa yang memiliki orang tua dengan wawasan pengetahuan atau keilmuan tahfiznya kurang, serta sibuk bekerja, maka peran terhadap kegiatan belajar tahfiz anaknya juga terbatas. Orang tua memberikan dorongan, pesan, nasehat, sanksi dan penghargaan kepada anaknya. Hal ini dilakukan guna menumbuhkan minat belajar tahfiz anak didik yang belajar di madrasah maupun di rumah. Oleh karena itu, orang tua telah melakukan perannya sebagai motivator, pendidik, penegak disiplin, serta pengatur atau pengontrol. Peran orang tua, tergantung tingkat pengetahuan dan dasar tahfiz, serta intensitas pertemuan orang tua dan anak didik dalam melakukan interaksi saat berada di rumah

Kata Kunci

Peran, Orang Tua, Guru, Pembelajaran, Tahfiz.

\section{INTRODUCTION}

Suasana belajar bersifat kolaboratif berguna untuk menciptakan pembelajaran yang terpadu, sehingga peserta didik mempunyai motivasi yang kuat dalam aktivitas belajarnya (Mandarakas, 2014), baik saat di rumah maupun di madrasah (Fauzan \& Arifin, 2019). Minat dapat didefenisikan dengan rasa suka, perhatian ketertarikan, fokus, pengetahuan, keterampilan, dan ketekunan (Dewey, 2001). Minat juga merupakan pedoman utama yang berguna bagi manusia untuk melaksanakan kegiatan secara optimal. Sebagai aspek yang berperan dalam pembangunan jiwa seseorang ini, minat tidak hanya bisa mempengaruhi perilaku atau perbuatan seseorang (Ajzen \& Fishbein, 2021), akan tetapi juga berperan untuk memotivasi seseorang untuk tetap melaksanakan dan mendapatkan sesuatu (Harackiewicz et al., 2016, Rifa'i et al., 2021).

Dalam Alquran juga telah diserukan secara tegas tentang manusia (insan) yang berilmu ini, yaki terdapat pada surat Al-Mujaadilah ayat 11. Dalam ayat tersebut terdapat fadilah atau keutamaan dari orang-orang yang beriman dan memiliki ilmu pengetahuan yakni mereka adalah manusia yang berhasil mendapatkan kemualiaan melalui diangkatkan derajatnya dari orang-orang lainnya. Sehingga menjadi peserta didik yang beriman serta berilmu pengatahuan juga menjadi salah satu bagian dari golongan ini. Hal ini tentu saja didukung oleh adanya kehadiran peran orang tua beserta guru guna mendukung pelaksanaan pembelajaran secara efektif dan berkelanjutan.

Sebagian aspek utama yang bisa berpengaruh terhadap pertumbuhan minat pribadi manusia yakni bertumpu pada kapasitas orang tua (Ritonga et al., 2021). Proses membentuk minat belajar tersebut bisa dipengaruhi oleh lingkungan seseorang bermain, interaksi dari teman sebaya (Booren et al., 2019), serta pola asuh orang tua merupakan faktor penyebaba yang bisa mempengaruhi minat manusia (Bi et al., 2018). Selanjutnya, supaya minat belajar tahfiz peserta didik di madrasah baik, maka diperlukan upaya yang konkret oleh orang tua (Nurlaili et al., 2020). Dalam hal ini, orang tualah sebagai penanggung jawab utama dalam pendidikan dalam mengontrol proses belajar anaknya di rumah (Suparman et al., 2020). Dengan kata lain, Di antara berbagai faktor bahwa keberhasilan peserta didik dalam proses belajar mata pelajaran tahfiz Islam adalah disebabkan peran orang tua peserta didik dalam melakukan pengawasan pada kegiatan belajar tahfiz Islam untuk anak didiknya.

Salah satu kiat pembelajaran yang dilaksanakan satuan pendidikan saat ini yakni melalui pembelajaran secara dalam jaringan (daring) dan luar jaringan (luring). Hal ini bermula dari adanya pandemi dari virus corona virus disease 19 (Covid 19) (Sartika et al., 2020). Demi kepentingan pelaksanaan pembelajaran tersebut, guru dan orang tua semestinya mampu bertindak sebagai fasilitator dan kontributor sesuai kemampuan dan 
bidang keahlian yang dimiliki (Azhar et al., 2020). Sebagai guru, tentu saja memiliki peran yang tidak terbatas dalam hal pemberian informasi pembelajaran yang bermakna pada peserta didik.

Salah satu peran guru tersebut yakni melaksanakan pembelajaran berbasis bahan ajar. Bahan ajar yang disiapkan guru tersebut didistribusikan kepada peserta didik untuk dipelajari dan dipahami para peserta didik di rumah masing-masing. Pada sisi yang lebih kreatif dan inovatif, sebagian guru melakukan pembelajaran online dengan memanfaatkan aplikasi pembelajaran yang telah tersedia di perangkat android, baik smartphone maupun perangkat komputer. Selama pandemi covid 19 ini, pembelajaran karakter peserta didik perlu memperoleh perhatian atau simpati yang lebih dari guru beserta orang tua, karena intensitas pertemuan tatap muka guru dan pendidik sangat terbatas. Sementara itu, setiap materi dalam palajaran tahfiz menargetkan para peserta didik mahir membaca ayat-ayat Alquran, hadits, dan penerapan karakter dalam beraktivitas bersama orang lain di lingkungan sekitarnya. Setelah peneliti melakukan pengamatan (observasi) pada para peserta didik, selanjutnya berdasarkan wawancara dengan guru tahfiz di MTsN 2 Pasaman, guru belum sepenuhnya melaksanakan pembelajaran daring dan luring secara maksimal selama masa pendemi Covid 19 ini. Guru menggunakan aplikasi whatsapp grup kelas untuk pembelajaran daring.

Oleh karena kendala yang terdapat selama proses pembelajaran daring dan luring tersebut, maka dapat berdampak pada peserta didik, sehingga kurang berminat serta memiliki motivasi dalam aktivitas belajar. Hasilnya, peserta didik terkendala saat memahami materi yang dipelajari. Padahal, materi tahfiz merupakan materi pokok yang sangat penting dalam pelaksanaan pendidikan di madrasah. Melalui pembelajaran tahfiz secara daring dan luring inilah guru dan peserta didik akan lebih mudah terbantu dan mudah melaksanakan pembelajaran dengan harapan peserta didik memiliki pemahaman yang cukup dan kepribadian berkarakter Islami. Pada saat peneliti melaksanakan observasi ke MTsN 2 Pasaman, terdapat persoalan yang penulis temukan selama pembelajaran yakni perlu peningkatan peran orang tua serta guru pada proses belajar yang dilalui secara daring dan luring, yang mana dapat berefek terhadap pemahaman, minat, dan penerapan pembelajaran tahfiz peserta didik di rumah masing-masing. Selanjutnya, peneliti tertarik melakukan pengamatan lebih lanjut di MTsN 2 Pasaman Kecamatan Rao Kabupaten Pasaman. Dari hasil observasi tersebut, peneliti meyimpulkan bahwa banyak peserta didik yang kurang berminat belajar tahfiz, terkhusus mata pelajaran tahfiz. Untuk itu, penulis mengangkat penelitian kualitatif ini dengan judul penelitian tesis yakni 'Peran Guru dan Orang Tua dalam Menumbuhkan Minat Menghafal Alquran bagi Peserta Didik di Masa New Normal.

\section{METHOD}

Penelitian pada tesis ini dilaksanakan dengan memilih metode melalui pendekatan kualitatif. Metode yang dipilih yakni dengan metode bersifat deskriptif. Bepijak pada pemaparan konsep dari Bogdan dan Taylor, bahwa kualitatif adalah langkah-langkah dari penelitian untuk dapat memperoleh data berupa deskripsi seperti data yang berupa rangkaian kata, berwujud tulisan dan atau secara lisan berdasarkan tingkah laku yang diobsevasi oleh si peneiti (Maleong, 2013). Sementara itu, dalam sumber lain juga menjelaskan bahwa metode deskriptif merupakan salag satu metode (cara) yang meneliti suatu objek dalam bentuk kelompok, misalnya suatu objek, seseorang atau 
manusia, suatu keadaan atau pun situasi, dan suatu perspektif yang ada saat ini (Nazir, 2015). Kemudian, metode deskripsi bertujuan untuk memberikan sebuah deskripsi atau gambaran maupun penjelasan secara terstruktur dan sistematis terkait dengan peristiwa yang diamati. Selanjutnya, karena penelitian kualitatif menggunakan latar alamiah, maka desain penelitian ini menggunakan desain pendekatan naturalistik. Pendekatan ini menekankan pada pencarian dan penemuan pemahaman dan pengertian seputar fenomena di suatu latar dalam konteks khusus (Maleong, 2013). Peneliti mempergunakan pendekatan kategori naturalistik ini dengan mempertimbangkan bahwa pada pendekatan ini lebih condong meneliti terhadap perspektif suatu peristiwa di suatu tempat tertentu atau daerah yang ditentukan. Sehingga penelitian deskriptif ini diharapkan dapat memaparkan peran orang tua serta guru pada aktivitas pembelajaran tahfiz di MTsN 2 Pasaman Kecamatan Rao Kabupaten Pasaman. Dalam pelaksanaannya, peneliti mencari data yang sebenarnya dari hasil penelitian di lapangan. Selanjutnya, data itu dikumpukan dan diolah untuk dibuatkan ke dalan hasil penelitian pada hasil dan pembahasan.

Bentuk penyajiannya ini secara deskriptif, yakni menggambarkan atau mendeskripsikan peristiwa dan kejadian yang ada. Peristiwa itu bisa berupa rekayasa manusia, maupun bersifat ilmiah. Kajian pada penelitian ini berbentuk kajian aktivitas, ciri khas, perubahan, interaksi, persamaan dan perbedaannya pada peristiwa lain (Sukmadinata, 2010). Penelitian deskriptif bertujuan untuk membuat hasil penelitian secara nyata, akurat, dan sistematis tentang rangkaian kejadian nyata dan karakteristik daerah dan masyarakat tertentu (Sumaidi, 2014). Penelitian ini dilakukan di MTsN 2 Pasaman Kecamatan Rao Kabupaten Pasaman Madrasah ini terletak di Jalan Medan-Padang, Desa Kubu Cotu, di jalan lintas Sumatra. Pelaksanaan penelitian ini dilaksanakan dari bulan Januari-Maret 2021. Desain penelitian berupa penelitian kualitatif dengan desain penelitian deskriptif korelasional. Jumlah populasi yang diamati adalah peserta didik di di MTsN 2 Pasaman. Peneliti memilih kelas sampel dengan penggunaan smartphone terbanyak yakni kelas VII-1 sebanyak 35 peserta didik dari 40 peserta didik. metode dan prosedur penelitian ini terdiri dari research idea, literature review, theoretical formulation of the research problem, empirical research questions (operationalization), dan research design (planning), data collection, data analysis, answering the empirical research questions, theoretical interpretation of the result, comparison with earther research, dan conclusion. Pendekatan penelitian ini melalui tahapan penelitian yaitu tahap pendahuluan, tahap persiapan, tahap penelitian, tahap penyusunan laporan akhir.

Subjek penelitian ini yakni orang tua, guru, kepala madrasah, dan tata usaha. Selanjutnya objek pada penelitian ini yakni tentang peranan orang tua dan guru dalam upaya peningkatan mutu pendidikan di MTsN 2 Pasaman, Rao, Pasaman. Teknik dalam pengumpulan data ini memakai teknik secara nontes yang tersusun sistematis. Prosedur pengumpulan data diambil dari data yang sesuai dengan permasalahan yang diteliti. Maka dari itu, untuk melihat sejauh mana peran orang tua dan guru dalam mendampingi anak saat melaksanakan aktivitas belajar dari rumah atau secara daring, peneliti melaksanakan suatu penelitian melalui teknik mengumpulkan data hasil observasi, wawancara, dan dokumentasi serta studi dokumenter. Pengumpulan data tersebut didapatkan pada penelitian ini dalam bentuk data wawancara dan dilaksanakan pengolahan data. Tahap awal peneliti melakukan telaah terhadap seluruh data yang diperoleh dari beragam sumber, diantaranya foto, gambar, dokumen resmi, angket, dan sebagainya. Sesuai dengan penjelasan tentang data tersebut, dapat dijelaskan bahwa semua data yang didapatkan itu dibaca, dipelajari, dan ditelaah. Pada tahap lanjut, 
peneliti mereduksi data, menyajikan data, serta mengambil kesimpulan. Prosedur analisis data ini dengan membuat data yang dikumpulkan untuk diolah sesuai dengan tujuan peneliti. Seluruh data yang telah terkumpul dari lapangan itu yang akan dianalisis secara keseluruhan. Bogdan dan Biklen mengungkapkan perihal analisis data adalah salah satu aktivitas mendeteksi dan manajemen yang sistematis berupa transkrip atau teks wawancara, catatan untuk keperluan lapangan, dan beberapa bahan baku terkait untuk digunakan dalam rangka peningkatan terhadap pemahaman terhadap berbagai bahan terkait untuk bisa diinterpretasikan hasil penemuannya untuk khalayak publik (Nurul, 2006).

Penelitian ini termasuk ke dalam penelitian lapangan yang berkategori kualitatif. Sehingga Peneliti memakai pendekatan bersifat deskriptif, yakni pendekatan yang bertujuan mengumpulkan data sebanyak mungkin, kemudian data tersebut digunakan untuk dianalisis memanfaatkan metode deskriptif. Makna deskriptif di sini adalah mengumpulkan data berbentuk perkataan, bisa berupa gambar-gambar, dan tidak termasuk angka-angka atau hitungan. Semua kegiatan tersebut dikarenakan peneliti menerapkan metode kualitatif. Pada tahap terpenting pada penelitian ini yakni berbagai data yang berhasil terkumpul tersebut berpeluang besar menjadi kata kunci terhadap objek yang telah diteliti (Maleong, 2000). Peneliti melakukan pendataan dengan membuat ringkasan, pengkodean, menghimpun catatan objektif dan penyimpanan data. Tahap analisis data (interactive model) yang dilalui yakni pengumpulan data, penelaahan data, menampilkan (display) data, dan menarik kesimpulan (Salim, 2016).

Selanjutnya, analisis data yang diperoleh pada penelitian ini, dilakukan dengan berdasarkan pada konsep Miles dan Huberman. Analisis adalah data kualitatif yang dilakukan secara interaktif melalui proses data reduksi, penyajian data, dan verifikasi data. Setelah data selesai telah berhasil terkumpul dari daerah lingkup penelitian melalui data wawancara, pengamatan atau observasi, dan data dokumentasi, maka dilaksanakan analisis penguraian serta pengambilan kesimpulan. Data yang telah berhasil direkapitulasi tersebut berlanjut pada proses pemasukan pada pola tertentu guna keperluan klasifikasi pada kategorinya, yakni pengumpulan varian data, mereduksi data, menyajikan data, serta menarik kesimpulan. Dalam hal pemeriksaan keabsahan data yang diperoleh, peneliti melakukan uji validitas. Ketentuan yang peneliti pakai dalam keabsahan data ini yakni data dapat disebut sebagai data valid, jikalau tidak ditemukan atau tidak ditemukan pembeda yang signifikan antara data laporan peneliti dengan aktivitas yang terjadi sesungguhnya terkait objek yang tengah diamati untuk penelitian. Untuk menguji tingkat validitas yang dilaksanakan pada penelitian tersebut juga melewati uji triangulasi serta ketersediaan bahan referensi.

\section{RESULTS\&DISCUSSION}

Temuan Penelitian pada penelitian ini yakni peran orang tua selama aktivitas belajar tahfiz di MTsN 2 Pasaman. Cakupan mengenai peran orang tua ini termasuk temuan yang kompleks. Artinya, berdasarkan data orang tua peserta didik dari lintas wawasan, profesi dan pengetahuan, maka peneliti membuat kelompok klasifikasi agar lebih mudah dikenali dan diindentifikasi. Klasifikasi tersebut peneliti dapatkan sesuai dengan hasil pengamatan (observasi) peneliti di MTsN 2 Pasaman. Peserta didik dengan orang tua yang berpengatahuan tahfiz dan berada di rumah. Orang tua pada kelompok ini merupakan kelompok yang senantiasa memperhatikan aktivitas anaknya saat berada 
di rumah. Hal ini disebabkan karena mereka memiliki kesempatan dan waktu yang relatif banyak dalam mendampingi anaknya belajar di rumah. Keterangan ini didukung berdasarkan keterangan wawancara peneliti terhadap orang tua peserta didik yang berhasil memberikan keteladanan melalui penerapan akhlak yang baik kepada anaknya. Kebiasaan yang terus dilakukan anaknya yaitu membaca bismillah sebelum makan dan mengenakan pakaian yang rapi dan sopan., selalu terlebih dahulu mencium tangan orang tua sebelum berangkat ke madrasah. Peserta didik dengan kategori orang tua yang kurang mempunyai wawasan atau dasar tahfiz serta lebih sibuk bekerja Dalam hal ini terdapat peserta didik yang memiliki orang tua dengan pengetahuan atau dasar tahfiz yang terbatas (kurang) dan kesibukan bekerja sehari-hari. Berdasarkan hasil pengamatan yang peneliti dapatkan, orang tua ini cukup sibuk dalam bekerja, sehingga kurang berinteraksi dengan anaknya serta kurang dapat membimbing anaknya secara utuh dalam pengerjaan tugas dari orang tuanya, terkhusus pada bidang studi tahfiz. Kondisi tersebut mesti dilandasi berdasarkan hasil wawancara yang telah peneliti laksanakan bersama orang tua dari peserta didik pula.

Peran orang tua dalam upaya menumbuhkan minat belajar tahfiz di MTsN 2 Pasaman. Ditekankan pada aspek perilku peserta didik terhadap aktivitas belajarnya, di antaranya dibagi berdasarkan tingkat antusiasme (mengikuti aktivitas belajar dengan penuh semangat) khususnya mata pelajaran tahfiz. Selanjutnya, peneliti memilih kelas dengan kriteria pengguna pembelajaran daring terbanyak di kelas 9 yaki kelas 97 dengan jumlah peserta didik sebanya 38 orang. Dari data tersebut, ditemukan seluruh peserta didik yang menyukai mata pelajaran tahfiz. Kemudian, pengamatan peneliti berlanjut dengan mengamati orang tua mata pelajaran tahfiz yang masuk ke kelas untuk melakukan pembelajaran bersama peserta didik. Seluruh peserta didik menyinak dan memahami materi yang disampaikan guru tahfiz di MTsN 2 Pasaman. Peserta didik yang memiliki orang tua berpengetahuan tahfiz yang baik dan berada di rumah diperoleh data bahwa mereka selalu memperhatikan anaknya dengan bertanya kepada anaknya sepulang sekolah. Misalnya, bertanya tentang kegiatan belajar di sekolah dan memeriksa buku pelajaran tahfiz (tahfiz) anaknya.

Orang tua juga menyempatkan untuk melakukan pendampingan dan pengawasan saat anaknya belajar di rumah, baik dengan melihat buku catatan dan latihan maupun pada buku paket dan buku cetaknya. Selain itu, apabila ada pertanyaan yang anaknya kurang mengerti atau sulit dipahami atau dikerjakan, maka orang tua tersebut turut serta memberikan bantuan sebisa mungkin dalam memberikan solusi dalam mengerjakan tugas anaknya. Bahkan, sebagai bentuk dukungan terhadap ketuntasan belajar anaknya, orang tua juga mencarikan orang tua les tambahan untuk menambah pemahaman tahfiznya, baik hafalan maupun wawasan pendidikannya. Berdasarkan wawancara yang peneliti lakukan dengan orang tua pada kategori ini terkait upaya menumbuhkan minat belajar tahfiz anaknya dapat memberikan dorongan atau motivasi dan penyemangat langsung tertuju pada anak dalam rangka upaya pertumbuhan minat belajar menghafal Alquran.

Peserta didik yang memiliki orang tua berpengetahuan tahfiz yang kurang dan sibuk bekerja diperoleh hasil bahwa mereka mengakui adanya keterbatasan komunikasi kurang, sehingga orang tua serta anak juga kurang saling mengetahui kegiatan dan perilaku anaknya saat pelaksanaan belajar di rumah. Sehingga, ketika suatu kali anaknya menanyakan tugasnya yang terbilang sulit, maka orang tua meminta bantuan istrinya atau malah menyuruh belajar dengan teman lain yang rumahnya tak jauh dari rumahnya. Hal ini terjadi dikarenakan adanya aktivitas padat orang tua selama bekerja 
di tempat kerja selain di rumah. Dari keterangan wawancara yang peneliti dapatkan pada kategori orang tua seperti ini dalam menumbuhkan minat belajarnya, maka diberikan arahan dan nasehat untuk terus membuat anaknya berminat dalam belajar. Berikut ini merupakan ungkapan beberapa arahan yang diberikan orang tua dari peserta didik Dari segi orang tua, peneliti mendapatkan keterangan dari orang tua mata pelajaran tahfiz, bahwa dalam pembelajaran di kelas, terjadi suasana belajar yang aktif. Hal tersebut karena orang tua menerapkan berbagai metode pembelajaran yang bervariasi yang menjadikan peserta didik dapat mengerti materi secara keseluruhan. Hal ini didukung oleh hasil wawancara peneliti dengan guru tahfiz menerangkan bahwa semuanya disesuaikan dengan kebutuhan materi dan peserta didik supaya berhasil diciptakan situasi yang menyenangkan, aktif, serta efektif.

Hasil penelitian terkait peran orang tua dan orang tua dalam upaya menumbuhkan minat pembelajaran tahfiz peserta didik yakni (1) Orang tua sebagai pemberi dorongan (motivator). Setelah melakukan observasi secara langsung ke lapangan, maka peneliti menemukan orang tua yang senantiasa perhatian kepada anaknya, dengan cara menanyakan tentang kegiatan belajar anaknya di madrasah. Selain itu, orang tua juga menyempatkan untuk melakukan pendampingan dan pengawasan pada anaknya dalam belajar dan mengerjakan tugas di rumah. Motivasi yang diberikan dalam bentuk lain adalah ketika anaknya bertanya tentang tugas yang terbilang sulit atau tidak bisa dimengerti. Maka orang tua tersebut tidak sungkan-sungkan untuk langsung membantu anaknya dalam mengerjakan pekerjaan rumah (PR) atau tugas yang diberikan orang tua. Dalam hasil wawancara di atas, peneliti mendapatkan orang tua yang semacam ini memaksimalkan perannya dengan menumbuhkan minat belajar anaknya melalui upaya-upaya yang bervariasi dalam menumbuhkan minat belajar tahfiz ankanya. Salah satunya dengan usaha pemberian dorongan serta semangat kepada anak didik guna menumbuhkan minat belajarnya. (2) Orang tua selaku pemberi perhatian belajar (pendidik). Berdasarkan hasil pengamatan yang peneliti lakukan, peneliti menemukan informasi bahwa orang tua terkait sering peduli dalam hal bertanya pada anak tentang kegiatan belajar tahfiz di madrasah.

Selanjutnya, selaku orang tua menaruh perhatian dengan menyempatkan memeriksa buku catatan setorn hafalan tahfiz sepulang dari madrasah. Setelah diketahui demikian, orang dengan peran semacam inilah yang berhasil dalam menumbuhkan minat belajar tahfiz anaknya. Secara tidak langsung ia telah menjalankan perannya sebagai pendidik di rumah bagi anaknya. (3) Orang tua selaku pemberi peringatan (teladan disiplin). Berdasarkan pengamatan yang telah peneliti lakukan, didapatkan informasi bahwa orang tua yang selalu menanamkan sifat kedisiplinan yang teratur dan berkelanjutan dalam belajar, memberikan pengaruh yang baik terhadap minat belajar anaknya. Beberapa contohnya yakni menjadwalkan waktu untuk belajar anaknya dan belajar tambahan di luar belajar bersama orang tua. Keteladanan dan kedisiplinan dalam hal ini mampu menumbuhkan minat belajar tahfiz (tahfiz) anaknya sebagai penegak disiplin, karena orang tua telah memberikan contoh dalam bertutur kata, bersikap, dan berbuat dalam kelas maupun di rumah. Sehingga dapat terbiasa saat peserta didik berada di luar kelas dan lingkungan sekitar. (4) Orang tua sebagai pengawas (pengontrol). Berdasarkan hasil pengamatan yang peneliti temukan, diperoleh informasi pula bahwa orang tua yang selalu mengawasi kegiatan belajar anaknya di rumah dan di sekolah, dapat membantu pelaksanaan perannya sebagai pengontorl atau pengawas dalam kegiatan belajar tahfiz anaknya di rumah. Beberapa contohnya yakni orang tua selalu memperhatikan pekembangan belajar tahfiz anaknya terhadap orang tua mata pelajaran 
tahfiz di sekolah. Dengan adanya pengawasan yang berkelanjutan seperti ini, orang tua dapat mengetahui seberapa peningkatan belajar ankanya. Hasil penelitian perihal peran guru dalam upaya menumbuhkan minat belajar tahfiz di MTsN 2 Pasaman yakni secara umum, peranan guru sebagai pendidik meliputi tiga belas macam yakni sebagai inspiratory, korektor. informator, pembimbing, fasilitator, inisiator, motivator, organisator, pengelola kelas, demonstrator, supervisor, mediator, dan evaluator. Secara umum, orang tua tahfiz telah melaksanakan semua peran tersebut sebagai insan pendidik dengan baik.

Pembahasan penelitian ini terdiri dari peran orang tua dalam pembelajaran tahfiz di MTsN 2 Pasaman, yakni pada prinsipnya, setiap orang tua telah melakuan perannya sesuai keahlian dan kondisi keluarga masing-masing. Artinya, berbagai peran telah dilaksanakan orang tua selama aktivitas mendampingi dan pembimbingan kegiatan pembelajaran tahfiz anaknya di rumah secara daring. Beberapa orang tua telah berhasil melakukan perannya secara utuh, mengingat dan memperhatikan orang tuanya berada di rumah dan mempunyai wawasan pengetahuan menghafal Alquran yang lebih baik. Maka dari itu, mereka dapat mudah dalam hal pemantaauan dan pemberian wawasan yang baik pula kepada anak didik, meskipun pembelajaran dilakukan secara daring. Selain itu, ada pula orang tua yang kurang dalam melaksanakan perannya. Penyebab utama yang membuat peran tersebut kurang terlaksana secara utuh ada beberapa hal. Kondisi tersebut memberikan dampak pada kegiatan pembelajaran tahfiz (hafalan Alquran) peserta didik, di luar dan dalam kelas. Orang tua yang melaksanakan perannya secara baik dalam pelaksanaan kegiatan pembelajaran tahfiz, maka anaknya di kelas menjadi hafiz dan hafizah, mampu bertutut kata, bersikap, atau berakhlak lebih sopan dan bisa menghargai serta menghormati rekan sejawat lainnya.

Sementara itu, orang tua yang relative kurang dalam melaksanakan perannya dengan maksimal, berpeluang dapat mengakibatkan efek pada anak didiknya. Misalnya anak menjadi kurang merespon saat pembelajaran di luar dan di dalam kelas. Secara sikap, maka jelas sudah si anak dalam bersikap dengan sesuka hati, karena keterbatasan wawasan dan bersikap secara santun di dalam kehidupan kelas dan luar kelas. Setelah menguraikan hasil penelitian di atas, maka peneliti mendapatkan informasi penting bahwa setiap orang tua mempunyai strategi atau pun cara tersendiri dan bervariasi dalam upaya menumbuhkan minat belajar tahfiz anak didiknya di rumah. Beberapa cara tersebut di antaranya memberikan kalimat-kalimat motivasi yang bertujuan memberikan nasehat kepada anaknya supaya lebih meningkatkan cara belajarnya, khususnya pada mata pelajaran menghafal alquran (tahfiz). Selain motivasi seperti contoh di atas, ada lagi orang tua yang memberikan ungkapan nasehat terbaik mereka kepada anaknya dalam rangka memberikan arahan dan peneguran kepada anaknya yang bermalasmalasan belajar tahfiz atau menghafal Alquran. Beberapa di antara orang tua juga memberikan apresisasi berupa pujian saat anaknya mendapatkan nilai bagus, atau meraih prestasi di kelas. Juga apresiasi dalam bentuk bermacam-macam yang diberikan orang tua kepada anaknya, misalnya dibelikan ponsel android untuk meningkatkan minat belajar secara daring.

Peran orang tua dalam pembelajaran tahfiz di MTsN 2 Pasaman yakni Pada prinsipnya, setiap orang tua telah melakuan perannya sesuai kemampuan dan kondisi keluarga masing-masing. Ada yang mengunakan media pembelajaran yang menarik dan ada pula yang hanya menggunakan metode klasik saja. Sehingga ada dua suasana belajar, yakni menarik dan monoton. Artinya, berbagai peran telah dilaksanakan orang tua dalam mendampingi dan pembimbingan aktivitas belajar tahfiz anaknya di rumah 
secara daring. Beberapa orang tua telah berhasil melakukan perannya secara utuh, mengingat dan memperhatikan orang tuanya berada di rumah dan memiliki wawasan pengetahuan hafalan Alquran yang lebih. Maka dari itu, mereka dapat dengan mudah melakukan pemantauan dan menunjang kepahaman yang lebih pula kepada anaknya, meskipun pembelajaran dilakukan secara daring. Selain itu, ada pula orang tua yang kurang dalam melaksanakan perannya. Penyebab utama yang membuat peran tersebut kurang terlaksana secara utuh ada beberapa hal. Kondisi tersebut memberikan dampak pada kegiatan pembelajaran tahfiz peserta didik baik di dalam, maupun di luar kelas. Orang tua yang melaksanakna perannya secara baik dalam pelaksanaan kegiatan pembelajaran tahfiz, maka anaknya di kelas mampu bertutur kata, bersikap, atau berakhlak lebih sopan dan santun dan mampu menghargai serta menghormati rekan sejawat yang lain. Sementara itu, orang tua yang relatif kurang dalam melaksanakan perannya secara maksimal, akan dapat menyebabkan efek terhadap anaknya. Misalnya anak menjadi kurang bersemangat dalam aktivitas belajar di dalam dan luar kelas. Secara sikap, maka jelas sudah si anak dalam bersikap dengan sesuka hati, karena keterbatasan wawasan dan bersikap secara santun di dalam kehidupan kelas dan luar kelas.

Peran guru dalam menumbuhkan minat belajar tahfiz di MTsN 2 Pasaman terlihat bahwa guru tahfiz selain menyampaikan materi, ia juga senantiasa memperlihatkan keteladanan dalam hal bertutur kata, bersikap, dan berbuat selama di kelas, maupun di luar kelas. Setelah menguraikan hasil penelitian di atas, maka peneliti mendapatkan informasi penting bahwa setiap orang tua mempunyai strategi atau pun cara tersendiri dan bervariasi guna menumbuhkan minat belajar tahfiz anaknya di rumah. Beberapa cara tersebut di antaranya memberikan kalimat-kalimat motivasi yang bertujuan memberikan nasehat kepada anaknya supaya lebih meningkatkan cara belajarnya, khususnya pada mata pelajaran menghafal alquran (tahfiz). Selain motivasi seperti contoh di atas, ada lagi guru yang memberikan ungkapan nasehat terbaik mereka kepada anaknya dalam rangka memberikan arahan dan peneguran kepada anaknya yang bermalas-malasan belajar atau mengerjakan tugas. Beberapa di antara orang tua juga memberikan apresisasi berupa pujian saat anaknya mendapatkan nilai bagus, atau meraih prestasi di kelas. Juga apresiasi dalam bentuk bermacam-macam yang diberikan orang tua kepada anaknya, misalnya dibelikan ponsel android untuk meningkatkan minat belajar secara daring..

\section{CONCLUSIONS}

Sesuai hasil dan pembahasan penelitian yang dipaparkan, peneliti menarik suatu kesimpulan bahwa peran orang tua peserta didik di MTsN 2 Pasaman Kecamatan Rao dapat ditentukan oleh tingkat pengetahuan, keberadaan orang tua, dan interaksi. Jadi, siswa yang memiliki orang tua dengan wawasan pengetahuan yang baik atau keilmuan tentang tahfiz juga baik, dan berada lebih banyak di rumah, maka peran orang tua dapat diberikan secara utuh terhadap kegiatan belajar tahfiz, sebab sering melakukan interaksi dengan anaknya. Sebaliknya, siswa yang memiliki orang tua dengan wawasan pengetahuan atau keilmuan tahfiznya kurang, serta keberadaan orang tua lebih banyak di luar rumah (sibuk bekerja), maka peran terhadap kegiatan belajar tahfiz anaknya juga terbatas, sebab kesibukan orang tuanya cukup menyita waktu belajar bersama anaknya.

Pada aspek upaya menumbuhkan minat belajar tahfiz anaknya, para orang tua melaksanakan upaya yang bervariasi seperti memberikan motivasi, pesan, nasehat, 
sanksi (punishment) dan penghargaan (reward) kepada anaknya. Hal ini dilakukan untuk menumbuhkan minat belajar tahfiz anaknya yang belajar di sekolah maupun di rumah. Maka dari itu, orang tua telah melakukan perannya sebagai motivator, pendidik, penegak disiplin, serta pengatur atau pengontrol. Segenap peran tersebut dilakukan berbeda-beda setiap orang tua, tergantung tingkat pengetahuan dan dasar tahfiz, serta intensitas pertemuan orang tua tua dan anak dalam melakukan interaksi selama di rumah. Oleh karena itu, minat peserta didik dipengaruhi oleh peran orang tua dan guru di madrasah.

\section{BIBILIOGRAPHY}

Ajzen, I., \& Fishbein, M. (2021). The Influence of Attitudes on Behavior. The Handbook of Attitudes, January 2005, 187-236. https://doi.org/10.4324/9781410612823-13

Azhar, Lahmi, A., Rasyid, A., Ritonga, M., \& Saputra, R. (2020). The Role of Parents in Forming Morality Adolescents Puberty in Globalization Era. International Journal of Future Generation Communication and Networking, 13(4), 3991-3996.

Bi, X., Yang, Y., Li, H., Wang, M., Zhang, W., \& Deater-Deckard, K. (2018). Parenting styles and parent-adolescent relationships: The mediating roles of behavioral autonomy and parental authority. Frontiers in Psychology, 9(NOV), 1-13. https://doi.org/10.3389/fpsyg.2018.02187

Booren, L. M., Downer, J. T., \& Vitiello, V. E. (2019). Observations of Children's Interactions with Teachers, Peers, and Tasks across Preschool Classroom Activity Settings. Early Childhood Research Quarterly, 23(5), 152-165. https://doi.org/10.1080/10409289.2010.548767.Observations

Dewey, J. (2001). Democracy and Education. In Educational Forum (Vol. 1, Issue 4). Pennsylvania State University. https://doi.org/10.1080/00131725209341529

Fauzan, F., \& Arifin, F. (2019). The Effectiveness of Google Classroom Media on the Students' Learning Outcomes of Madrasah Ibtidaiyah Teacher Education Department. Al Ibtida: Jurnal Pendidikan Guru MI, 6(2), 271-285. https://doi.org/10.24235/al.ibtida.snj.v6i2.5149

Harackiewicz, J. M., Smith, J. L., \& Priniski, S. J. (2016). Interest Matters: The Importance of Promoting Interest in Education. HHS Public Access, 3(2), 220-227. https://doi.org/10.1177/2372732216655542

Lexy J Maleong. 2000. Metodologi Penelitian Kualitatif. Bandung: Remaja Rosdakarya

Mandarakas, M. (2014). Teachers and Parent-School Engagement: International Perspectives on Teachers' Preparation for and Views about Working with Parents. Global Studies of Childhood, 4(1), 21-27. https://doi.org/10.2304/gsch.2014.4.1.21

Maleong, L. J. 2013. Metodologi Penelitian Kualitatif. Bandung: Remaja Rosdakarya 2013. Metodologi Penelitian Kualitatif. Bandung: Remaja Rosdakarya, hal 4 - 5.

Nazir, Moh. 2015. Metode Penelitian.Bogor: Ghalia Indonesia

Nurlaili, Ritonga, M., \& Mursal. (2020). Muroja'ah sebagai metode menghafal al quran studi pada rumah tahfiz yayasan ar-rahmah nanggalo padang. Menara Ilmu, XIV(02), 1-5.

Nurul Zuriah. 2006. Metode Penelitian Sosial dan Pendidikan, Teori Aplikasi. Jakarta: Bumi Aksara 
Rifa'i, A., Hidayati, E., \& Purnamasari, S. (2021). The Psychological Condition of STIQ Amuntai Student's in Learning Arabic. Tanwir Arabiyyah: Arabic as Foreign Language Journal, 1(1), 15-24. https://oi.org/10.22219/afl.v1i1.2482

Ritonga, M., Sartika, F., \& Kustati, M. (2021). Madrasah al-Ula for Children: An Effective Learning Management in the Family during Covid-19 Pandemic. Ilkogretim Online Elementary Education Online, 20(1), 968-976. https://doi.org/10.17051/ilkonline.2021.01.97

Sartika, F., Ritonga, M., \& Rasyid, A. (2020). Implementation of Islamic Religious Education in Madrasah Ibtidaiyah During Covid-19 Pandemic. Khalifa: Journal of Islamic Education, $4(2), 97-117$.

Suparman, Untoro, I. H. T., Suwadi, Prabowo, A., Andriyani, Humanika, E. S., Hairun, Y., \& Ritonga, M. (2020). The Implementation of Community Partnership Program to Improve the Quality of Online Learning during the Covid-19 Pandemic. Universal Journal of Educational Research, 8(11 B), 6134-6138. https://doi.org/10.13189/ujer.2020.082249 
